\title{
Nanosponges: A Viable option for Combating Covid-19
}

\author{
R. Biswasi \\ Applied Optics and Photonics Lab, Department of Physics, Tezpur University, Tezpur, Assam, India.
}

Corresponding author: R. Biswas, Applied Optics and Photonics Lab, Department of Physics, Tezpur University, Tezpur, Assam, India.

Received date: August 24, 2020; Accepted date: September 17, 2020; Published date: September 21, 2020

Citation: R. Biswas, (2020). Nanosponges: A Viable option for Combating Covid-19. J Clinical Research and Reports, 5(4); DOI:10.31579/2690$1919 / 121$

Copyright: () 2021, R. Biswas. This is an open access article distributed under the Creative Commons Attribution License, which permits unrestricted use, distribution, and reproduction in any medium, provided the original work is properly cited.

Abstract:
This brief communication appraises nanosponges regarding their potential application in drug industry. Initiating from
their basics, their particular characteristics are briefed. Apart from this, one of the very recent application of
nanosponges is outlined along with future perspectives.
Key Words: nanosponges; drug industry; hydrophilic; lipophilic; inhalation; vaccines; virus; potential;
nhibitionary mode

\section{Summary:}

Nanosponges resembles minuscule mesh-like assemblies. Their sizes are less than one $1 \mu \mathrm{m}$. Moreover, they are porous in nature. We can in other words say that these sponges embodies very tiny cavities with resemblance as pores. As a result, it can act as potential carrier for drugs, which possess lower solubility [1-3]. These drugs can be effectively loaded via these nanosponges, which in turn results efficient bioavailability as well as solubility. This helps in controlled delivery of a broad range of drugs including hydrophilic and lipophilic, as well as dosage. They can be made in different dosage forms. Some of them may be parenteral, tropical, oral as well as inhalation based. They propagate until they attain their target. They then bind themselves to the surface and gradually start releasing the loaded drugs in a controlled way.

Of late, the recent pandemic has made our lives very miserable [4]. The world economy has been badly impacted. Throughout the world, there are trials going on for finding a total cure for Covid-19.

Meanwhile, USA, RUSSIA, UK have been quite busy in developing the vaccines.

Simultaneously, certain groups are embarking on project where they could apply the latest Nano technological advancement in order to curb SARS-COV-2. As we know that this virus atatcks the lung cells. Scientists are in large engaged in research where this virus can be deceived by making a decoy. Accordingly, Zhang et al. 2020 [2] were successful in producing a biomimetic decoy. They utilized nanosponges towards this purpose. They made an arrangement of tricking the virus so that it latches to coated nanoparticles in lieu of host cells. These advanced nanosponges mimic living cells and immune cells. Thereby, they act as tiny decoy and lure the coronavirus away from lung cells. As a result, it prevents SARS-COV-2 from infecting cells and replicability. The nanosponges are loaded with tiny bio friendly polymers. They then impersonate as cell membranes. Precisely, it can be visualized as nanoparticles coated in the cell membrane.

In general, lung membranes remain as the potential target for SARSCOV-2. Once, they reach this, they initially bind to lung membranes, thereby starting replication. On the contrary, if the polymer droplets remain attached to cell membranes, they become more attacking towards SARS-COV-2 through immediate binding with them, thereby obstructing them to infect lung cells. Finally, the virus is destroyed once it is totally sucked to the cell fragments embodying the nanosponge droplet.

Accordingly, researchers coated nanosponges with lung cells and immune cells. Surprisingly, the the $90 \%$ of the infectivity related to SARS-COV2 is lost. For just a mere concentration of $5 \mathrm{mg} / \mathrm{ml}$, the lung- and macrophage membrane-cloaked sponges inhibited up to $93 \%$ and $88 \%$ of SARS- CoV-2 infectivity, respectively. This is executed in inhibitionary mode. Meanwhile, if a therapeutic dose of nanosponges is administered, it will then fill the lung cell with around 1 trillion tiny nano sponges; which is quite adequate to diver the attention of the virus from the healthy cells. Noteworthy point is that the body immune system easily eliminate these nanospones as well as the virus trapped inside them. Thanks to their biodegradable nature. Additionally, it has been reported that nanosponges exhibit the potential of suppressing cytokine storms in COVID 19 patient. Herein, the nanosponges is masked with the macrophages' cell. It is achievable through immune cells coated nanosponges. This leads to extra bonus of tracking the immune response as well as the virus.

However, immune markers imply short-term safety. This requires more in-depth analysis in order to assess the efficacy of nanosponges. It is important to mention here these results are performed in cell culture dishes, which ought to be extended to other animal models as well as further clinical trials. Long term and sustainable biocompatibility is another crucial parameter [3]. Additionally, it is equally important to devise effective strategies towards injecting these nanosponges into lungs of incubated patients. We may cite for example, inhalation or as a precrisptory medium for curbing cytokine storm. Only time will say. 
There is no doubt in saying that these membrane-cloaked nanoparticles can be regarded as a robust candidate in combating SARS-CoV-2 [3]. Their usefulness hold only if the host receptor for virus cell invasion remains intact. These nanosponges harness tremendous potential towards antiviral therapy spanning a broader spectrum that lie ahead to be investigated in detail.

\section{References:}

1. P. Pandey, D. Purohit, Harish Dureja, Nanosponges -A Promising Novel Drug Delivery System, Recent Pat Nanotechnol, 2018;12(3):180-191.
2. Q. Zhang, A. Honko, J. Zhou, H. Gong, S. N. Downs, J. H. Vasquez, R. H. Fang, W. Gao,Griffiths, L. Zhang, Cellular nanosponges inhibit SARS-CoV-2 infectivity. Nano Lett. 10.1021/acs.nanolett.0c02278 (2020).

3. Su Xinyi, Nanosponges intercept coronavirus infection, Science Translational Medicine 01 Jul 2020: Vol. 12, Issue 550, eabd3078.

4. R. Biswas, Are Men More Vulnerable to Covid-19 as Compared to Women? Biomed J Sci \& Tech Res 27(2)-2020. BJSTR. MS.ID.004481.
This work is licensed under Creative Commons Attribution 4.0 License

DOI: $10.31579 / 2690-1919 / 121$

Ready to submit your research? Choose Auctores and benefit from:

$>$ fast, convenient online submission

$>$ rigorous peer review by experienced research in your field

$>$ rapid publication on acceptance

$>$ authors retain copyrights

$>$ unique DOI for all articles

$>$ immediate, unrestricted online access

At Auctores, research is always in progress.

Learn more auctoresonline.org/journals/journal-of-clinical-research-andreports 